\title{
Maternal body mass index and external cephalic version success rate - are they related?
}

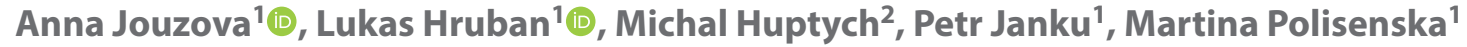 \\ ${ }^{1}$ University Hospital Brno, Department of Obstetrics and Gynecology, Medical Faculty, Masaryk University, Czech Republic \\ ${ }^{2}$ Czech Institute of Informatics, Robotics, and Cybernetics, Czech Technical University in Prague, Czech Republic
}

\begin{abstract}
Objectives: External cephalic version (ECV) is a useful method helping to reduce the incidence of planned caesarean deliveries for fetal malpresentation. There is an effort to look for the best predictors for a successful ECV, the effect of maternal weight is still unclear.

The aim of our study is to determine maternal body mass index (BMI) in association with the ECV success rate and the risk of complications.

Material and methods: A retrospective observational cohort study in 981 women after the $36^{\text {th }}$ week of gestation with a fetus in a breech presentation who had undergone an ECV attempt. We evaluated the success rate and complications of ECV in association with BMI categories according to the WHO classification of obesity.

Results: ECV was successful in 478 cases (48.7\%). In the category of overweight patients (BMI $>25 ; n=484$ ), ECV was successful in $51 \%$ and unsuccessful in $49 \%$ ( $p=0.28$ ) of cases. In obese patients (BMI > 30; $n=187$ ), ECV was successful in $44.8 \%$ and unsuccessful in $55.2 \%(p=0.28)$ of cases. The effect of BMI on the success rate of ECV for the category of overweight and obesity was not proven by statistical analysis. Serious complications occurred in seven cases in similar numbers in all three subgroups according to BMI.

Conclusions: BMI in the categories of overweight and obesity is not a factor influencing the success rate and risk of complications of ECV. These results can be helpful when consulting pregnant women the chance of successful ECV.
\end{abstract}

Key words: external version; breech presentation; pregnancy; maternal obesity; body mass index

Ginekologia Polska 2021; 92, 6: 423-427

\section{INTRODUCTION}

One of the methods allowing reduction of the incidence of planned caesarean sections for the breech presentation of the fetus is the external cephalic version (ECV), the overall success rate of the method is about $50 \%$ [1]. External cephalic version is a safe procedure that is not associated with a higher rate of perinatal complications [1-3]. Despite this, the fear for complications may be the cause of the mother's concerns about the procedure - about $25 \%$ of women reject ECV and more than $40 \%$ feel a fear of pain and are worried about fetal safety $[4,5]$. Due to this there is an effort to select patients who would be more or less suitable for the procedure.
A large number of factors potentially influencing the success rate of the ECV are still being the subject of discussion. Although there are a lot of prediction models and scoring systems that should help increase the success rate of the procedure they are, unfortunately, rather inconsistent [6]. Increasing parity, posterior placenta, amount of amniotic fluid, the position of parts of the fetus are the most frequently cited positive predictors of successful external version. Other factors, such as estimated fetal weight, palpation of the fetal head, fundal height and uterine tension, are questionable [6-12]. Maternal weight is also one of these factors under discussion $[9,13,14]$. Overweight and obesity are a great obstetric issue, especially as the prevalence of 
overweight women and pre-pregnancy obesity has been increasing rapidly over the last decade [15]. Overweight itself represents a significant risk of comorbidities in pregnancy and in overweight women, caesarean section is associated with a higher level of complications $[16,17]$.

\section{Objectives}

Attempting successful ECV could reduce the incidence of potential complications due to surgical procedure. Our retrospective study aimed to determine $\mathrm{BMI}$ at the time of the ECV as an independent factor of the success rate of the procedure.

\section{MATERIAL AND METHODS}

A retrospective observational cohort study was conducted at the Department of Obstetrics and Gynaecology, Masaryk University, University Hospital Brno, Czech Republic. We collected data for ECV performed between January 2003 and December 2019.

A total of 992 women who underwent ECV were recruited. Eleven participants were excluded because we failed to obtain their complete data and $981 \mathrm{ECV}$ cases were further analysed. We assessed the weight of all patients at the time of the procedure and according to this, we divided all patients into four groups according to WHO classification of obesity (i.e. $\mathrm{BMI}<25$ - normal weight, $\mathrm{BMI} \geq 25$ - overweight, BMI $\geq 35$ - obesity, BMI $\geq 40$ - morbid obesity). All ECV included in the study were performed by three experienced obstetricians. All participants in the study were $\geq 36+0$ weeks of gestation, signed a declaration of informed consent to the procedure.

Our standardized clinical protocol for ECV was always respected - exclusion criteria for ECV were ruptured membranes, vaginal bleeding, uterine abnormality, contraindications of vaginal delivery, signs of intrauterine fetal distress and fetal malformations [18]. Prior to ECV, vaginal examination and cardiotocography (CTG) was performed, an ultrasound was used to determine the estimated fetal weight (EFW), amount of amniotic fluid, placental location, and type of breech presentation. The maximum time limit for ECV was ten minutes. The intravenous tocolytic agent (Hexoprenaline $10 \mathrm{ug}+100 \mathrm{~mL}$ of $0,9 \% \mathrm{NaCl}$ ) was applied and no analgesia used in all attempts. The ultrasound for monitoring the fetal position, fetal heart rate and placental status was used at all time during the procedure. After each ECV a CTG of a minimum length of 45 minutes was recorded and another one was done within two hours. If physiologically well, the patient was discharged (after an ultrasound check and a (TG) in most cases, on the following day.

Characteristics of the study population and obstetric factors are listed in Table 1 - other recorded factors were the success rate of external cephalic version and mode of de- livery. In addition, serious complications associated with ECV (bleeding, placental abruption, intrauterine fetal distress with the need for an emergency caesarean section within 24 hours, intrauterine fetal death) were carefully noted.

The primary outcome was to determine the effect of BMI on the success rate of ECV. The secondary outcome was to define complications of ECV related to BMI.

Data was collected and analysed using statistical analysis. Continuous values were expressed as medians and ranges of the parameter and evaluated for all three BMI groups by the Kruskal-Wallis test. The Mann-Whitney test and Bonferroni correction were used for post hoc analysis of the pairwise comparison of BMI groups. Categorical parameters were compared using the Chi-square test for all three BMI groups and Fisher's exact test with Bonferroni correction was utilized in a pairwise comparison. The logistic regression model with a stepwise selection method was built for the multivariable analysis. The odds ratio (OR) statistic was used for the evaluation of parameters in the multivariable analysis. A p-value lower than 0.05 was considered to be significant. Statistical analyses were performed in MedCalc Statistical Software version 19.2.6 (MedCalc Software Ltd, Ostend, Belgium; https://www.medcalc.org; 2020).

\section{RESULTS}

From the total number of 981 women, the external cephalic version was successful in 478 cases (48.7\%). Concerning the baseline characteristics of the study group - parity, placental localization and type of breech were not significantly different in all BMI groups. There was an inter-group difference in maternal age and estimated fetal weight of the fetus ( $p=0.004$ for age, $p<0.001$ for the EFW) (Tab. 1).

To the subgroup of women with a $\mathrm{BMI} \geq 30$, six women with a $\mathrm{BMI} \geq 40$ (morbidly obese) were added - due to the low number of participants, it was not possible to evaluate them separately. Of these six cases, ECV was successful in two cases, one woman after successful ECV delivered vaginally and five women by caesarean section.

Using univariate analysis of $\mathrm{BMI}$ as a continuous factor, there was no statistically significant effect on the success rate of the ECV $(p=0.45)$. Concerning the fact that it is clinically useful testing the BMI by WHO categories, a univariate analysis was performed for standard categories. This analysis also did not show a significant impact of BMI on the success rate of the ECV ( $p=0.28)$ (Tab. 1).

In multivariate analysis, the category of $\mathrm{BMI} \geq 30$ is significantly important $(p=0.012)$, but the resulting odds ratio $(\mathrm{OR}=1.58)$ demonstrates only a small effect of this BMI category on the success rate of ECV (Fig. 1) [19, 20]. Further testing revealed that, after the separation of six cases of morbid obesity (BMI $\geq 40$ ), all BMl categories in the multivariate analysis are also of no significance. 


\begin{tabular}{|c|c|c|c|c|c|}
\hline Variables & $\begin{array}{c}\text { Total } \\
(n=981)\end{array}$ & $\begin{array}{l}\mathrm{BMI}<25 \\
(\mathrm{n}=310)\end{array}$ & $\begin{array}{l}\mathrm{BMI} \geq 25 \\
(\mathrm{n}=484)\end{array}$ & $\begin{array}{l}\mathrm{BMI} \geq 30 \\
(\mathrm{n}=187)\end{array}$ & p-value \\
\hline $\begin{array}{l}\text { Maternal age [years] } \\
\text { Median } \\
\text { Range }\end{array}$ & $\begin{array}{c}31 \\
17-44\end{array}$ & $\begin{array}{c}30 \\
17-42\end{array}$ & $\begin{array}{c}31 \\
20-44\end{array}$ & $\begin{array}{c}31 \\
22-44\end{array}$ & 0.004 \\
\hline $\begin{array}{l}\text { Parity } \\
\text { Nulliparous } \\
\text { Multiparous }\end{array}$ & $\begin{array}{l}638(65.0 \%) \\
343(35.0 \%)\end{array}$ & $\begin{array}{l}207(66.8 \%) \\
103(33.2 \%)\end{array}$ & $\begin{array}{l}314(64.9 \%) \\
170(35.1 \%)\end{array}$ & $\begin{array}{c}117(62.6 \%) \\
70(37.4 \%)\end{array}$ & 0.63 \\
\hline $\begin{array}{l}\text { Gestational age at ECV [weeks] } \\
\text { Median } \\
\text { Range }\end{array}$ & $\begin{array}{c}38 \\
35-41\end{array}$ & $\begin{array}{c}38 \\
35-41\end{array}$ & $\begin{array}{c}38 \\
35-41\end{array}$ & $\begin{array}{c}38 \\
35-41\end{array}$ & 0.07 \\
\hline $\begin{array}{l}\text { Type of breech } \\
\text { Frank } \\
\text { Non-Frank }\end{array}$ & $\begin{array}{l}724(73.8 \%) \\
257(26.2 \%)\end{array}$ & $\begin{array}{c}234(75.5 \%) \\
76(24.5 \%)\end{array}$ & $\begin{array}{l}354(73.1 \%) \\
130(26.9 \%)\end{array}$ & $\begin{array}{c}136(72.7 \%) \\
51(27.3 \%)\end{array}$ & 0.71 \\
\hline $\begin{array}{l}\text { Estimated Fetal weight [grams] } \\
\text { median } \\
\text { range }\end{array}$ & $\begin{array}{c}2900 \\
1900-4200\end{array}$ & $\begin{array}{c}2800 \\
2000-3840\end{array}$ & $\begin{array}{c}2900 \\
1900-3900\end{array}$ & $\begin{array}{c}3000 \\
2200-4200\end{array}$ & $<0.001$ \\
\hline $\begin{array}{l}\text { Amniotic fluid amount (MVP in mm) } \\
<40 \mathrm{~mm} \\
\geq 40 \mathrm{~mm}\end{array}$ & $\begin{array}{l}152(15.6 \%) \\
823(84.4 \%)\end{array}$ & $\begin{array}{c}54(17.5 \%) \\
255(82.5 \%)\end{array}$ & $\begin{array}{c}74(15.4 \%) \\
408(84.6 \%)\end{array}$ & $\begin{array}{c}24(12.8 \%) \\
163(87.2 \%)\end{array}$ & 0.41 \\
\hline $\begin{array}{l}\text { Placental location } \\
\text { Anterior wall } \\
\text { Non-anterior wall }\end{array}$ & $\begin{array}{l}381 \text { (39.0\%) } \\
595(61.0 \%)\end{array}$ & $\begin{array}{l}107(34.5 \%) \\
203(65.5 \%)\end{array}$ & $\begin{array}{l}199(41.5 \%) \\
281(58.5 \%)\end{array}$ & $\begin{array}{c}75(40.3 \%) \\
111(59.7 \%)\end{array}$ & 0.14 \\
\hline $\begin{array}{l}\text { Outcome of ECV } \\
\text { Success } \\
\text { Failure }\end{array}$ & $\begin{array}{l}478(48.7 \%) \\
503(51.3 \%)\end{array}$ & $\begin{array}{l}148(47.7 \%) \\
162(52.3 \%)\end{array}$ & $\begin{array}{l}247(51.0 \%) \\
237(49.0 \%)\end{array}$ & $\begin{array}{c}83(44.4 \%) \\
104(55.6 \%)\end{array}$ & 0.28 \\
\hline $\begin{array}{l}\text { Delivery mode }{ }^{\ddagger} \\
\text { Spontaneous vaginal } \\
\text { Caesarean section }\end{array}$ & $\begin{array}{l}566(57.9 \%) \\
412(42.1 \%)\end{array}$ & $\begin{array}{l}193(62.9 \%) \\
114(37.1 \%)\end{array}$ & $\begin{array}{l}284(58.7 \%) \\
200(41.3 \%)\end{array}$ & $\begin{array}{l}89(47.6 \%) \\
98(52.4 \%)\end{array}$ & 0.003 \\
\hline $\begin{array}{l}\text { Delivery mode (successful ECV only) } \\
\text { Spontaneous vaginal } \\
\text { Caesarean section }\end{array}$ & $\begin{array}{c}477(48.6 \%) \\
385(80.7 \%) \\
92(19.3 \%)\end{array}$ & $\begin{array}{c}129(87.8 \%) \\
18(12.2 \%)\end{array}$ & $\begin{array}{c}199 \text { (80.6\%) } \\
48 \text { (19.4\%) }\end{array}$ & $\begin{array}{l}57(68.7 \%) \\
26(31.3 \%)\end{array}$ & 0.002 \\
\hline $\begin{array}{l}\text { Serious complications } \\
\text { Yes } \\
\text { No }\end{array}$ & $\begin{array}{c}7(0.7 \%) \\
974(99.3 \%)\end{array}$ & $\begin{array}{c}1(0.3 \%) \\
309(99.7 \%)\end{array}$ & $\begin{array}{c}3(0.6 \%) \\
481(99.4 \%)\end{array}$ & $\begin{array}{c}3(1.6 \%) \\
184(98.4 \%)\end{array}$ & \\
\hline
\end{tabular}

BMI — body mass index; ECV — external cephalic version; MVP — Maximum Vertical Pocket; † Missing information of placental location in five cases ( $0.5 \%$ ); $¥$ Missing information of the delivery mode in three cases $(0.3 \%)$; §Delivery mode of successful external cephalic versions only

Women after successful ECV had a vaginal delivery in 80.7\% (385/477) versus 36.1\% (181/501) after an unsuccessful ECV. After successful ECV in the category of normal weight (BMI < 25), $87.8 \%$ patients delivered vaginally, in overweight patients (BMI $\geq 25$ ) $80.6 \%$ succeeded in spontaneous labour and in the category of the obesity ( $\mathrm{BMI} \geq 30$ ), $68.7 \%$ of the patients had vaginal delivery (Tab. 1).

Another finding is the relationship between increasing age and $\mathrm{BMI}$, but using continual analysis, we prove this correlation negligible.

We noted serious complications with the need for an emergency caesarean section in seven cases $(0.7 \%)$, these complications occurred in similar numbers in all three subgroups according to BMI (Tab. 1). Two caesarean sections were performed due to vaginal bleeding immediately after
ECV, in one case, vaginal bleeding occurred 36 hours after ECV and placental abruption was confirmed. The four other caesarean sections were performed as a result of pathological CTG after an ECV. In six of seven cases, the physiological $\mathrm{pH}$ values from the umbilical artery were confirmed, the Apgar score and postnatal status of the newborn were physiological in all seven cases.

\section{DISCUSSION}

The overall success rate of ECV in our study group reached $48,7 \%$ and represents a stable success rate of ECV at our department, consistent with the literature $[1,6]$. In the Czech Republic, it is strongly recommended that ECV is performed from the 36 weeks +0 days of gestation [18]. 


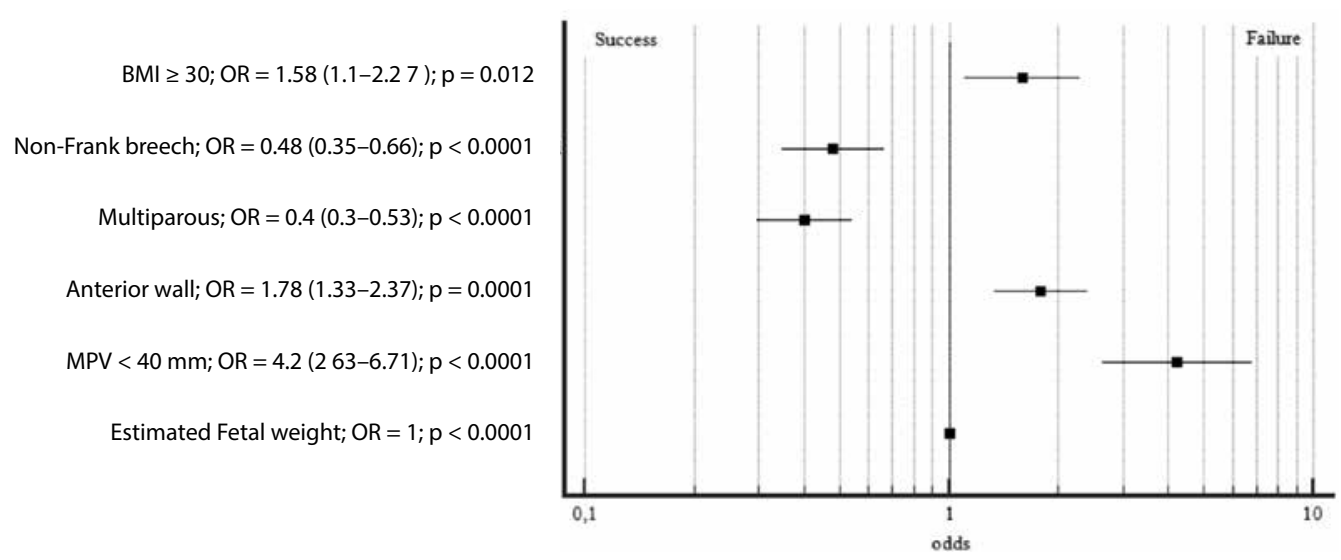

Figure 1. Multivariate odds ratios (OR) with confidence variables for the success rate of external cephalic version (ECV) based on different parameters and category body mass index $(\mathrm{BMI}) \geq 30$

When attempting an external cephalic version in an overweight woman, it can be assumed that the thicker the abdominal wall is, the more difficult is the handling and turning of the fetus so the success rate is lower [8]. Measuring the thickness of the abdominal wall objectively is difficult in practice, the body mass index assessment still seems to be the simplest and most appropriate method for estimating body status, excluding inter- and intra-observer disagreement [9]. There are numerous studies predicting the success rate of ECV due to variable factors, but just a few studies dealing with the relationship between success rate and maternal weight in particular. Chaudhary et al. has evaluated a large group of 51002 ECV and he showed a slightly worse success rate in morbidly obese patients (BMI > 40) [21]. Holman et al. in a group of 135 patients didn't prove the relation [22]. Other studies showed that maternal BMI can affect the success rate $[5,14]$ or not $[8-10,23,24]$ but the size of these groups ranged between 67 and 250 patients. In our group of 981 patients who underwent ECV we showed there to be no significant difference in the success rate of ECV in the categories of overweight and obesity. We have also demonstrated that higher BMI values are associated with increasing fetal weight (established as EFW) - this fact is already proven by many studies; obese women have a higher chance of the delivery of macrosomic or higher weight infant [29-30].

Another interesting finding is the relationship between increasing age and BMI. In the study of Lin et al. [28] women over 40 years of age had a higher incidence of overweight. Veghari et al. [29] also showed a coincidence between maternal age, birth weight and BMI. We hypothesized that this is because of the hormonal changes during pregnancy and age-related changes in body fat distribution and metabolism (lower secretion of growth hormone and responsiveness to TSH, higher leptin resistance) [28]. Using continual analysis, the correlation was negligible which means that this dependency is not so strong as to affect the final results. Apart of maternal age and estimated fetal weight, other factors (parity, gestational age at ECV, type of breech, amniotic fluid amount and placental location) are independent.

We have also confirmed that higher BMI values are significantly associated with a decrease in the success rate of vaginal births in the group of successful ECV $(87.8 \%, 80.6 \%$ and $68.7 \%$ in the subgroups of $\mathrm{BMI}<25, \mathrm{BMI} \geq 25$ and $\mathrm{BMI} \geq 30$ ) (Tab. 1). This can be well justified by the negative effect of obesity on vaginal births - the rate of caesarean delivery increased with a rise in maternal weight regardless of ECV outcome. There are some potential factors which may be contributing to lower rates of vaginal delivery after successful ECV among obese women: a higher rate of labour dystocia probably due to an adverse effect on uterine contractility, more frequent macrosomia and also a different deposition of soft tissue within the maternal pelvis [25-27, 30].

In our study we demonstrated that the complications rate is low and stable even if BMI increases.

The weakness of our study is a small group of morbidly obese women amounting of only six patients so we didn't evaluate this group separately. It can be assumed that in the group of morbidly obese the success rate is lower. Chaudhary et al. prove this hypothesis on a group of 2,128 morbidly obese women [OR 0.756 (0.691-0.827)] [21] (but morbid obesity in his study in the USA represents $4.2 \%$ vs $0.6 \%$ in our group).

Another disadvantage of the study may be the fact, that the assessment of being overweight during pregnancy as body mass index may not be perfectly accurate. It is possible to think about the different weight gain of the fetus, the amount of amniotic fluid, swelling. Currently, we don't have an easier and more precise method for the evaluation of maternal obesity. 
The strength of our study is the size of the group and respected standardized clinical protocol for ECV and a stable team of performing, experienced obstetricians.

\section{CONCLUSIONS}

On a large sample using retrospective analysis, we ruled out BMI as an independent factor influencing the success of external cephalic version - a relationship between pregnant women with their BMI in the category overweight and obese and the success rate of ECV was not shown. While counselling women about the probability of successful ECV, weight parameters should not be considered a contraindication to the procedure - moreover, this method should be offered to overweight patients in particular, which could reduce the incidence of potential complications associated with the surgical procedure of caesarean section. External version is a safe procedure helping to reduce caesarean delivery rates.

\section{Acknowledgements}

Supported by Ministry of Health, Czech Republic - conceptual development of research organization (FNBr, 65269705).

\section{Conflicts of interest}

The authors report no conflicts of interest.

\section{REFERENCES}

1. External Cephalic Version and Reducing the Incidence of Term Breech Presentation: Green-top Guideline No. 20a. BJOG. 2017; 124(7): e178-e192, doi: 10.1111/1471-0528.14466, indexed in Pubmed: 28299867.

2. Breech presentation: South Australian Perinatal Practice Guideline n.d.:13. https://www.sahealth.sa.gov.au/wps/wcm/connect/2277f480 4ee1e4adae3aafd150ce4f37/Breech+presentation_June2014.pdf?MO $D=A J P E R E S \& C A C H E I D=2277 f 4804 e e 1$ e4adae3aafd150ce4f37.

3. Hruban $L$, Janků $P$, Jordánová $K$, et al. [External cephalic version of breech fetus after 36 weeks of gestation - evaluation of efectiveness and complications]. Ceska Gynekol. 2017; 82(6): 443-449, indexed in Pubmed: 29302977.

4. Wágnerová $K$, Hruban L, Janků P. External cephalic version after 36th week of gestation - Analysis of women's perspective. Ceska Gynekol. 2017; 82: 355-361.

5. Ciliacus E, van der Zalm M, Truijens SE, et al. Fear for external cephalic version and depression: predictors of successful external cephalic version for breech presentation at term? BMC Pregnancy Childbirth. 2014; 14: 101, doi: 10.1186/1471-2393-14-101, indexed in Pubmed: 24620740.

6. Kok M, Cnossen J, Gravendeel L, et al. Clinical factors to predict the outcome of external cephalic version: a metaanalysis. Am J Obstet Gynecol. 2008; 199(6): 630.e1-7; discussion e1, doi: 10.1016/j.ajog.2008.03.008, indexed in Pubmed: 18456227.

7. Salzer L, Nagar R, Chen R, et al. 583: Predictors of successful external cephalic version and assessment of success for vaginal delivery. Am J Obstet Gynecol. 2014; 210(1): S287-S288, doi: 10.1016/j.ajog.2013.10.616.

8. Indraccolo U, Graziani C, Di lorio R, et al. External cephalic version for singleton breech presentation: proposal of a practical check-list for obstetricians. Eur Rev Med Pharmacol Sci. 2015; 19(13): 2340-2353, indexed in Pubmed: 26214768.

9. Cho LY, Lau WL, Lo TK, et al. Predictors of successful outcomes after external cephalic version in singleton term breech pregnancies: a nine-year historical cohort study. Hong Kong Med J. 2012; 18(1): 11-19, indexed in Pubmed: 22302905.
10. Ebner F, Friedl TWP, Leinert E, et al. Predictors for a successful external cephalic version: a single centre experience. Arch Gynecol Obstet. 2016; 293(4): 749-755, doi: 10.1007/s00404-015-3902-z, indexed in Pubmed: 26437955.

11. Limaye $\mathrm{M}$, Abdullahi $\mathrm{N}$, Has $\mathrm{P}$, et al. Factors Associated with Attempted External Cephalic Version for Fetal Malpresentation at Term. AJP Rep. 2019; 9(4): e323-e327, doi: 10.1055/s-0039-1695748, indexed in Pubmed: 31620311.

12. Velzel J, de Hundt M, Mulder FM, et al. Prediction models for successful external cephalic version: a systematic review. Eur J Obstet Gynecol Reprod Biol. 2015; 195: 160-167, doi: 10.1016/j.ejogrb.2015.10.007, indexed in Pubmed: 26546757.

13. Lim PS, Ng BK, Ali A, et al. Successful external cephalic version: factors predicting vaginal birth. ScientificWorldJournal. 2014; 2014: 860107, doi: 10.1155/2014/860107, indexed in Pubmed: 24587759.

14. Zandstra $\mathrm{H}$, Mertens $\mathrm{HJ}$. Improving external cephalic version for foetal breech presentation. Facts Views Vis Obgyn. 2013; 5(2): 85-90, indexed in Pubmed: 24753933.

15. Chaudhary S, Contag S, Yao R. 862: External cephalic version and complication rates according to maternal body mass index. Am J Obstet Gynecol. 2017; 216(1): S493, doi: 10.1016/j.ajog.2016.11.771.

16. Ayres-de-Campos D. Obesity and the challenges of caesarean delivery: prevention and management of wound complications. Best Pract Res Clin Obstet Gynaecol. 2015; 29(3): 406-414, doi: 10.1016/j.bpobgyn.2014.08.009, indexed in Pubmed: 25457856.

17. Vegel AJ, Benden DM, Borgert AJ, et al. Impact of Obesity on Cesarean Delivery Outcomes. WMJ. 2017; 116(4): 206-209, indexed in Pubmed: 29323807.

18. BinderT,UnzeitigV,Velebil P.Vedení prenatální péčea porodu donošeného plodu v poloze koncem pánevním - doporučený postup n.d.:2. http:// www.lekaridnes.cz/wp-content/uploads/2016/08/p-2013-vedeni-prenatalni-pece-a-porodu-donoseneho-plodu-v-poloze-koncem-panevnim.pdf.

19. Cohen J. Statistical power analysis for the behavioral sciences. 2 nd ed. Erlbaum Associates, Hillsdale 1988.

20. Borenstein M. Introduction to meta-analysis. John Wiley \& Sons, Chichester 2009.

21. Chaudhary S, Contag S, Yao R. The impact of maternal body mass index on external cephalic version success. J Matern Fetal Neonatal Med. 2019; 32(13): 2159-2165, doi: 10.1080/14767058.2018.1427721, indexed in Pubmed: 29355061.

22. Holman M, Ainsworth A, Weaver A, et al. Does Maternal Body Mass Index or Weight Gain Affect External Cephalic Version Success? [19H]. Obstetrics \& Gynecology. 2016; 127(Supplement 1), doi: 10.1097/01. aog.0000483696.90759.d7.

23. Mowat A, Gardener G. Predictors of successful external cephalic version in an Australian maternity hospital. Aust N Z J Obstet Gynaecol. 2014; 54(1): 59-63, doi: 10.1111/ajo.12152, indexed in Pubmed: 24359099.

24. Morgan ER, Hu AE, Brezak AMV, et al. Predictors of a successful external cephalic version: A population-based study of Washington state births. Women Birth. 2019; 32(3): e421-e426, doi: 10.1016/j. wombi.2018.08.001, indexed in Pubmed: 30150151.

25. Averett SL, Fletcher EK. Prepregnancy Obesity and Birth Outcomes. Matern Child Health J. 2016; 20(3): 655-664, doi: 10.1007/s10995-015-18650 , indexed in Pubmed: 26515472.

26. Zhao $\mathrm{R}, \mathrm{Xu} \mathrm{L}, \mathrm{Wu} M \mathrm{ML}$, et al. Maternal pre-pregnancy body mass index, gestational weight gain influence birth weight. Women Birth. 2018 31(1): e20-e25, doi: 10.1016/j.wombi.2017.06.003, indexed in Pubmed: 28716548.

27. Alves P, Malheiro MF, Gomes JC, et al. Risks of Maternal Obesity in Pregnancy: A Case-control Study in a Portuguese Obstetrical Population. Rev Bras Ginecol Obstet. 2019; 41(12): 682-687, doi: 10.1055/s-00393400455, indexed in Pubmed: 31856286.

28. Jura M, Kozak LP. Obesity and related consequences to ageing. Age (Dordr). 2016; 38(1): 23, doi: 10.1007/s11357-016-9884-3, indexed in Pubmed: 26846415.

29. Veghari G. Maternal age and BMI in relation to infant birth size: a study in public health centers in the north of Iran. Int J Med Res Health Sci. 2016; 5(9): 151-155.

30. Vinayagam $D, C$ andraharan $E$. The adverse impact of maternal obesity on intrapartum and perinatal outcomes. ISRN Obstet Gynecol. 2012; 2012: 939762, doi: 10.5402/2012/939762, indexed in Pubmed: 23316381. 